\title{
PEMETAAN HABITAT PERAIRAN DANGKAL MENGGUNAKAN CITRA RESOLUSI MENENGAH DENGAN METODE KLASIFIKASI BERBASIS PIKSEL (STUDI KASUS PULAU TIKUS)
}

\author{
Ari Anggoro, Zamdial, Dede Hartono, Deddy Bakhtiar, \\ Nurlaila Ervina Herliany, Maya Angraini Fajar Utami \\ Program Studi IImu Kelautan, Fakultas Pertanian, Universitas Bengkulu, \\ Bengkulu, Indonesia \\ E-mail : arianggoro@unib.ac.id
}

Received March 2020, Accepted April 2020

\begin{abstract}
ABSTRAK
Pulau Tikus adalah pulau kecil yang terletak di Kota Bengkulu yang memiliki potensi terumbu karang disekitar perairan dangkal. Tujuan penelitian ini untuk memetakan kawasan habitat perairan dangkal ekosistem terumbu karang Pulau Tikus menggunakan citra satelit Landsat $8 \mathrm{OLI}$ dan menguji akurasi klasifikasi peta habitat perairan dangkal di Pulau Tikus. Metode klasifikasi yang digunakan adalah klasifikasi terbimbing maximum likelihood classification. Hasil klasifikasi citra Landsat 8 OLI berdasarkan skema klasifikasi yang digunakan dari lima kelas habitat di Pulau Tikus tersebut yaitu karang hidup seluas 71,46 ha, karang campur pasir 106,9425 ha, karang mati 67,365 ha, makro alga 31,815 ha, dan pasir 40,05 ha. Uji akurasi dari perbandingan hasil klasifikasi citra dan data lapangan mendapatkan total akurasi keseluruhan yaitu sebesar $77 \%$.
\end{abstract}

Kata Kunci : Landsat 8 OLI, Klasifikasi Terbimbing, Pulau Tikus, Terumbu Karang

\section{ABSTRACT}

SHALLOW WATER HABITATS MAPPING USING A MEDIUM RESOLUTION IMAGE WITH CLASSIFICATION METHOD PIKSELBASED (CASE STUDY OF THE TIKUS ISLAND). Tikus Island is a small island which located in Bengkulu City has the potential of coral reefs around the shallow water. The aims of this research were to map the area of benthic habitat in Tikus Island Bengkulu using Landsat 8 OLI satellite imagery and to test the accuracy on the benthic habitat map in Tikus Island. The method used supervised classification using maximum likelihood classification. The result of Landsat $8 \mathrm{OLI}$ classification base on the five class habitats classification scheme used obtained in Tikus island showed coral reef $(71,46$ ha), coral mix sand $(106,9425$ ha), dead coral (67,365 ha), macroalgae (31,815 ha), and sand (40,05 ha). Accuracy test 
from the comparison of classification results and ground truth data get a total overall accuracy of $77 \%$.

Keywords : Landsat $8 \mathrm{OLI}$, Supervised Classification, Tikus Island, Coral Reef

\section{PENDAHULUAN}

Pulau Tikus terletak di Sebelah Barat Kota Bengkulu dengan jarak $10 \mathrm{~km}$ dari pantai Malabero dan berada di Samudera Hindia. Secara geografis terletak pada titik koordinat 3050'17,55" LS dan 102010'50,59" BT. Pulau Tikus merupakan pulau kecil yang terletak dalam wilayah administrasi Kota Bengkulu Kecamatan Teluk Segara Kelurahan Malabero yang dikelilingi terumbu karang dan kaya dengan sumber daya ikan.

Terumbu karang memberi peranan yang penting dalam ekosistem pesisir terutama pada pulau-pulau kecil seperti di Pulau Tikus. Keberadaan Pulau Tikus semakin hari keberadaanya semakin memprihatinkan karena terus terkikis oleh abrasi dan aktifitas antropogenik yang cenderung merusak. Pulau Tikus memiliki luas semula 2 ha, saat ini tersisas sekitar 0,8 ha dengan kepemilikan lahan Kementerian Perhubungan. Pulau Tikus terus mendapatkan tekanan secara alami dan adanya aktivitas manusia. Kerusakan terumbu karang di Pulau Tikus saat ini diduga karena adanya aktivitas manusia yang memanfaatkan sumberdaya terumbu karang secara tidak terkendali diantaranya penangkapan ikan menggunakan alat tangkap yang tidak ramah lingkungan seperti alat tangkap trawl dan jaring lobster, penjualan teumbu karang untuk souvenir serta penangkapan gurita dengan cara membongkar karang (Bakhtiar dan Ta'alidin, 2015).

Penginderaan jauh (remote sensing) adalah teknik yang dikembangkan untuk memperoleh dan menganalisis informasi tentang bumi dimana informasi tersebut khusus berbentuk radiasi gelombang elektromagnetik yang dipancarkan atau dipantulkan dari permukaan bumi (Sutanto, 1986). Berbagai satelit penginderaan jauh telah banyak dimanfaatkan untuk pemetaan habitat perairan dangkal terumbu karang. Satelit penginderaan jauh yang digunakan dengan variasi resolusi spasial tingkat menengah hingga resolusi tinggi. Namun dibalik kuantitas pemanfaatan teknologi tersebut terdapat kesulitan dan permasalahan khusus, yaitu kesulitan pada lingkungan bawah air adalah pengaruh variabel kedalaman pada reflektan dasar perairan (Mumby et al., 1997). Permasalahan yang dihadapi dalam aplikasi penginderaan jauh adalah dalam menentukan tingkat akurasi dan ketidakpastian (uncertainity) (Congalton dan Green, 2009).

Pendekatan yang umum pemantauan lingkungan terumbu karang, ketersediaan data pengamatan lapangan menjadi sangat terbatas. Hal ini disebabkan karena pengamatan lapangan membutuhkan banyak data transek untuk pemantauan lingkungan terumbu karang yang luas. Dengan demikian akan membutuhkan biaya dan tenaga yang intensif sehingga menjadi sangat sulit jika lokasi terumbu karang berada pada daerah yang 
sulit dijangkau. Penginderaan jauh merupakan pendekatan yang efektif untuk melengkapi keterbatasan pengamatan lapangan meskipun pemantauan terumbu karang dilakukan pada daerah yang sulit dijangkau. Oleh karena itu penggunaan data penginderaan jauh sangat memungkinkan untuk pemantauan status lingkungan terumbu karang (Green et al., 2002).

Klasifikasi dan analisis citra penginderaan jauh telah menjadi konsep dalam mengekstraksi informasi tertentu, memprediksi perubahan secara dinamis, pemetaan tematik dan membangun basis data penginderaan jauh untuk diimplementasikan pada keperluan tertentu. Seiring dengan perkembangan teknologi komputer, teknologi analisis digital citra penginderaan jauh juga mengalami perkembangan dari interpretasi visual ke klasifikasi dengan bantuan komputer untuk mengklasifikasi objek secara otomatis menggunakan metode klasifikasi berbasis piksel. Klasifikasi penginderaan jauh secara perlahan-lahan berkembang dari pengenalan secara fisik piksel tunggal, ektraksi informasi spektral dan tekstur menjadi pemahaman secara komprehensif (Zhu, 2003). Penerapan klasifikasi berbasis piksel untuk pemetaan habitat perairan dangkal dengan variasi algoritma klasifikasi telah menghasilkan peta dengan akurasi yang berbeda-beda (Green et al., 2002).

Teknologi penginderaan jauh sangat bermanfaat dalam menjawab permasalahan ekosistem terumbu karang. Kemampuan teknologi ini dapat menjangkau wilayah yang luas dengan resolusi spasial, resolusi spektral, resolusi radiometrik dan resolusi temporal yang baik serta efisien dalam penggunaannya. Berdasarkan uraian tersebut peneliti tertarik untuk melakukan penelitian terkait pemetaan habitat perairan dangkal menggunakan citra satelit tingkat resolusi menengah di Pulau Tikus.

Habitat perairan dangkal memiliki peranan penting pada wilayah pesisir, akan tetapi belum banyak dikenal dan diperhatikan serta dimanfaatkan secara optimal. Keberadaan habitat perairan dangkal sangat perlu untuk diketahui sebaran dan luasan menggunakan teknik pemetaan dari citra satelit. Teknik pemetaan mengunakan citra satelit sebagai data awal acuan untuk monitoring, kondisi habitat perairan dangkal, serta perubahan terhadap habitat tersebut karena aktivitas manusia dan alam. Sebagai ekosistem pesisir, habitat perairan dangkal sangat rentan sekali dan terancam keberadaanya yang dapat menurunkan populasinya di alam. Kerusakan ekosistem dapat terjadi akibat aktivitas manusia atapun aktivitas alam. Dikhawatirkan hilangnya habitat peraian dangkal akan semakin meningkat seiring dengan meningkatnya aktivitas manusia di daerah pesisir. Bila aktivitas manusia meningkat maka akan berdampak pada menurunnya kualitas perairan pesisir dan akan berdampak pada menurunnya fungsi dari ekosistem tersebut. Penelitian ini diharapkan dapat menjadi data acuan pemetaan awal mengenai habitat perairan dangkal di Pulau Tikus serta dapat diketahui pemanfaatanya secara berkelanjutan.

Tujuan umum dari penelitian ini adalah mendapatkan data sebaran dan habitat perairan dangkal ekosistem terumbu karang di Pulau Tikus berbasis piksel yang dapat digunakan sebagai data awal pengelolaan 
ekosistem terumbu karang di Pulau Tikus yang berkelanjutan. Adapun tujuan spesifik dari penelitian ini yaitu memetakan habitat perairan dangkal dari citra satelit resolusi menengah dengan teknik klasifikasi berbasis piksel dan melakukan pengujian akurasi pada peta habitat perairan dangkal di Pulau Tikus Kota Bengkulu.

\section{MATERI DAN METODE}

\section{Waktu dan Tempat Penelitian}

Penelitian ini dilaksanakan di Pulau Tikus Kota Bengkulu selama 3 bulan pada tahun 2019 (Gambar 1).

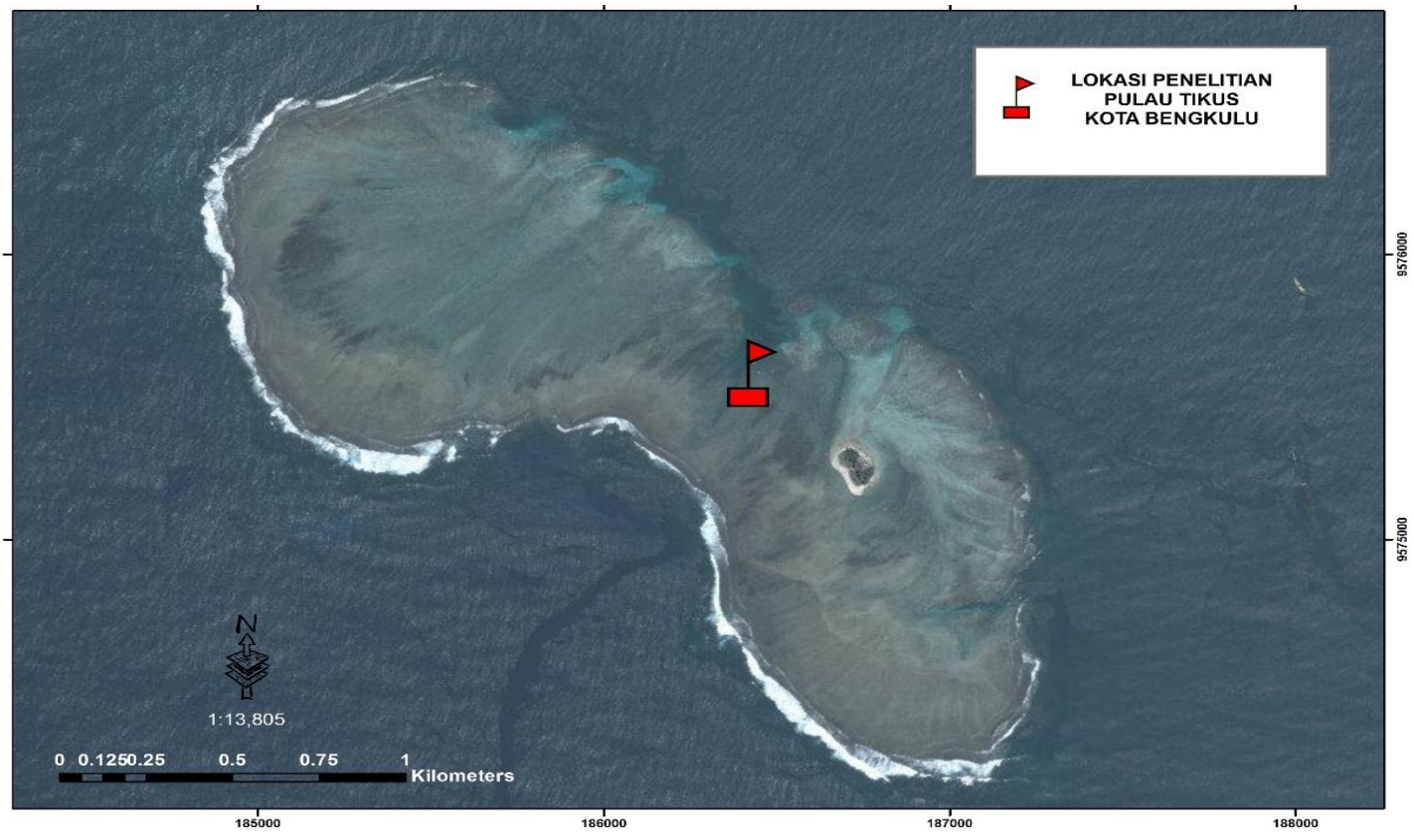

Gambar 1. Lokasi penelitian

Peralatan yang digunakan dalam penelitian ini terdiri dari perangkat keras pengolahan data, perangkat lunak dan peralatan pengambilan data di lapangan. Perangkat keras yang digunakan untuk pengolahan data adalah Personal Computer prosesor Intel Core i7, RAM 16 GB, media penyimpanan $1 \mathrm{~TB}$. Perangkat lunak digunakan untuk membantu proses pengolahan data terdiri dari: LibreOffice, DNR Garmin Versi 5.4, dan QGIS. Peralatan yang digunakan untuk pengumpulan data lapangan terdiri dari peralatan perekaman data koordinat, pengambilan data substrat dasar perairan dangkal, dokumentasi dan pencatatan data. Citra satelit multispectral Landsat-8 OLI tanggal 27 Mei tahun 2019 yang diperoleh dari situs http://earthexplorer.usgs.gov/. 


\section{Pengumpulan Data Lapangan}

Pengumpulan data lapangan terdiri dari kegiatan pengumpulan data habitat perairan dangkal untuk input klasifikasi citra dan uji akurasi. Pengumpulan data didasarkan pada skema klasifikasi dan resolusi spasial citra yang digunakan. Skema klasifikasi pada penelitian ini berdasarkan data yang dikumpulkan saat survei dengan mempertimbangkan kategori utama komponen penyusun terumbu karang yang terdiri dari 5 kelas habitat perairan dangkal yaitu pasir, karang hidup, karang mati, karang campur pasir, makro alga. Pengambilan data komponen ekosistem terumbu karang dilakukan dengan menggunakan metode Underwater Photo Transect (UPT) (Giyanto, 2013). Transek garis dibentangkan sepanjang 50 meter dan pengambilan data habitat dasar terumbu karang didasarkan pada bentuk pertumbuhan (life form) yang memiliki kode-kode tertentu (English et al., 1994).

\section{Pengolahan Citra}

Pengolahan citra satelit terdiri dari koreksi geometrik, koreksi radiometrik, koreksi atmosferik, pemotongan citra (cropping) wilayah kajian, masking dan koreksi kolom perairan. Pengolahan data koreksi geometrik, koreksi radiometrik dan koreksi atmosferik dilakukan terhadap citra asli pada band-band yang akan digunakan dalam analisis. Citra hasil koreksi tersebut selanjutnya dilakukan pemotongan (cropping) yang dibatasi pada wilayah kajian, kemudian menghilangkan nilai perairan dalam dan daratan (masking) dan koreksi kolom perairan (Lyzenga, 1981).

\section{Klasifikasi Citra}

Klasifikasi berbasis piksel pada habitat perairan dangkal dilakukan dengan teknik klasifikasi secara terbimbing mengacu pada data pengamatan lapangan dengan aturan klasifikasi maximum likelihood. Klasifikasi terbimbing adalah teknik pengelompokan piksel citra yang tidak diketahui menjadi sampel yang mempunyai identitas berdasarkan hasil pengamatan lapangan pada lokasi training area. Pengguna mendefenisikan training area dengan identifikasi region pada citra kemudian disesuaikan dengan hasil pengamatan lapangan. Untuk mengaplikasikan aturan klasifikasi yang digunakan, maka teknik training area (Aol) yang digunakan pada klasifikasi citra berdasarkan data pengamatan. Tahap klasifikasi selanjutnya adalah melakukan analisis perbandingan hasil klasifikasi citra satelit Landsat 8 OLI terhadap akurasi citra, luasan, dan sebaran habitat perairan dangkal.

\section{Uji Akurasi}

Pengujian akurasi dilakukan terhadap seluruh peta hasil klasifikasi untuk mengetahui akurasi dari teknik klasifikasi yang diterapkan. Uji akurasi yang umum dilakukan pada data hasil klasifikasi penginderaan 
jauh adalah matrik kesalahan (error matrix/confusion matrix atau contingency matrix). Hal ini dilakukan dengan membandingkan citra hasil klasifikasi sebagai peta terhadap kelas yang sebenarnya. Kelas yang sebenarnya diperoleh dari hasil pengamatan lapangan.

Uji akurasi mengacu kepada Congalton dan Green (2009). Pesentase ketelitian suatu kelas diperoleh dari perbandingan jumlah piksel yang benar masuk pada training area dengan jumlah piksel pada training area suatu kelas. Persentase ketelitian klasifkasi secara keseluruhan dihiting dari perbandingan antara jumlah piksel yang benar setiap kelas dengan total pixel training area keseluruhan.

\section{HASIL DAN PEMBAHASAN}

\section{Pengelolaan dan Analisis Citra}

\section{Pemotongan Citra}

Pemotongan citra merupakan proses dalam preprocessing citra sebelum diolah sesuai dengan daerah penelitian yang dibutuhkan. Pemotongan citra bertujuan untuk memfokuskan liputan citra pada daerah penelitian saja, sehingga proses pengolahan data, intepretasi visual, dan analisis data menjadi lebih sederhana atau hanya fokus pada daerah penelitian. Pemotongan citra pada lokasi penelitian di perairan pulau Tikus dapat dilihat pada Gambar 2 di bawah ini.

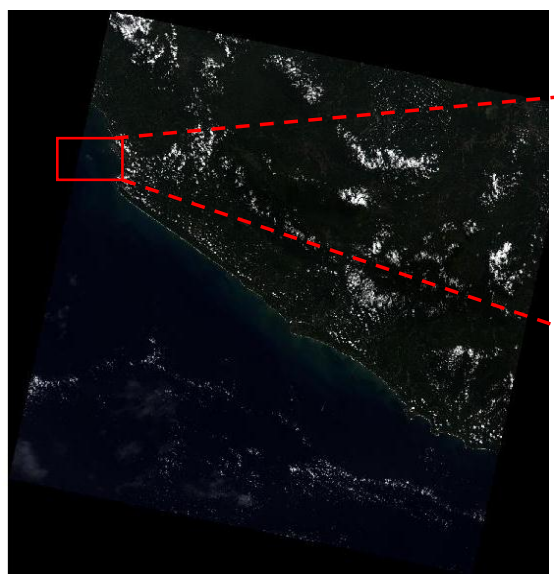

a

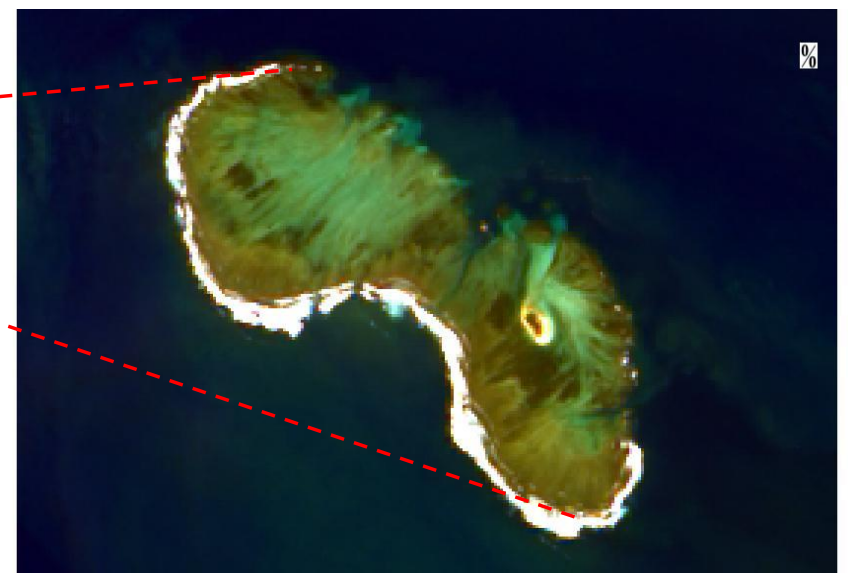

b

Gambar 2. a. Citra Landsat-8 (OLI) sebelum cropping; b. Citra Landsat-8 (OLI) setelah dilakukan pemotongan citra (cropping).

\section{Koreksi Geometrik}

Koreksi geometrik dilakukan pada citra untuk meperbaiki posisi objek pada citra sesuai dengan posisi sebenarnya dilapangan yang disebabkan oleh distorsi geometris. Distorsi geometris ini dapat disebabkan beberapa hal yaitu terjadinya rotasi bumi pada waktu 
perekaman, pengaruh kelengkungan bumi, efek panoramik (sudut pandang), pengaruh topografi, pengaruh gravitasi bumi yang menyebabkan terjadinya perubahan kecepatan dan ketinggian satelit dan ketidakstabilan ketinggian platform (Jaya, 2002). Pada penelitian pemetaan terumbu karang di perairan pulau Tikus ini dilakukan koreksi geometrik menggunakan koordinat referensi dari citra Google earth. Citra google earth ini digunakan karena ketelitiannya lebih detail dibandingkan citra Landsat-8.

\section{Koreksi Radiometrik}

Koreksi radiometrik merupakan pembetulan citra akibat kesalahan radiometrik atau cacat radiometrik. Menurut Purwadhi, (2001) Koreksi radiometrik ini bertujuan untuk memperbaiki nilai piksel agar sesuai dengan warna asli. Koreksi radiometrik merupakan perbaikan akibat kesalahan padasistem optik, kesalahan karena gangguan energi radiasi elektromagnetik pada atmosfer dan kesalahan karena pengaruh sudut elevasi matahari. Hasil dari citra yang sebelum dan sesudah dilakukan koreksi radiometrik dapat dilihat pada Gambar 3 di bawah ini.

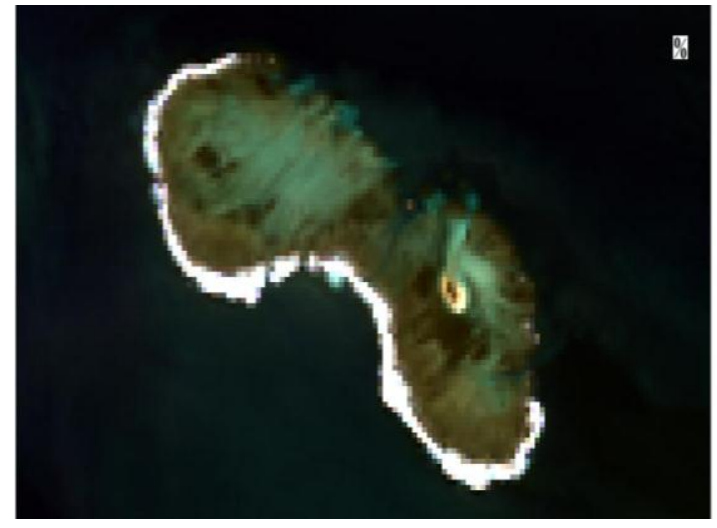

a

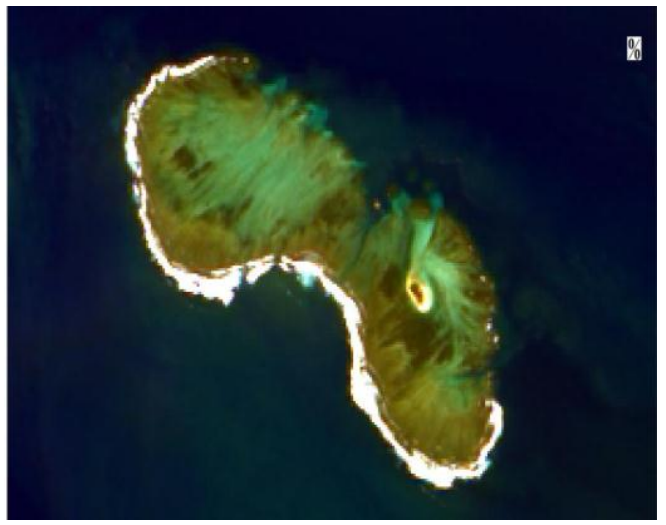

$\mathrm{b}$

Gambar 3. a. Citra Landsat-8 (OLI) sebelum dilakukan koreksi radiometrik; b. Citra Landsat-8 (OLI) setelah dilakukan koreksi radiometrik.

\section{Koreksi Kolom Perairan}

Koreksi kolom air dilakukan untuk memperbaiki kualitas citra dengan jalan mengurangi gangguan yang berada di kolom air. Teknik yang umum digunakan untuk koreksi kolom air adalah berdasarkan pada algoritma yang dikembangkan oleh Lyzenga (1981). Pada koreksi kolom air dilakukan penitikan dengan 43 titik pasir dengan kedalaman yang bervariasi. Regresi linier sampel piksel objek pasir kolom air pulau Tikus pada band green dan band blue yang sudah ditransformasi menggunakan logaritma natural (Ln). Grafik regresi linier dapat dilihat pada Gambar 4 di bawah ini. 


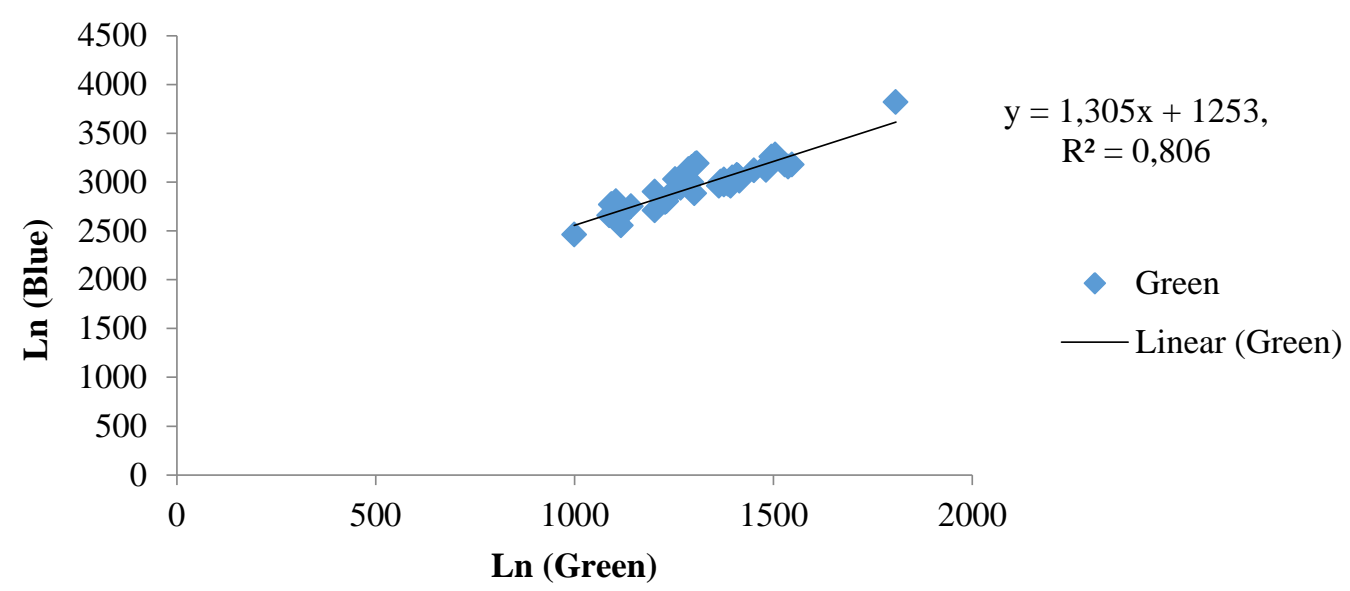

Gambar 4. Grafik regresi linier pada pasangan band green dan band blue

Berdasarkan pada Gambar 4, diperoleh persamaan y $=1,305 x+$ 1253. Nilai $1,305 \mathrm{x}$ merupakan slope dari garis linier atau rasio koefisien atenuasi dari pasangan band $(\mathrm{Ki} / \mathrm{Kj})$, sedangkan 1253 merupakan intercept garis linier yang merupakan nilai atau indeks dari objek pasir. $Y$ merupakan sumbu yang dibentuk dari trasnformasi natural logaritma band blue, sedangkan $X$ merupakan sumbu yang dibentuk dari transformasi logaritma natural band green. Nilai dari rasio koefisien atenuasi pasangan band $(\mathrm{Ki} / \mathrm{Kj})$ digunakan pada algortima DII (Depth Invariant Index) yaitu citra terkoreksi kolom air dengan nilai digital berupa indeks objek habitat dasar perairan dangkal. DII menghasilkan citra baru yang merupakan pasangan band green dan band blue (Gambar 5.)

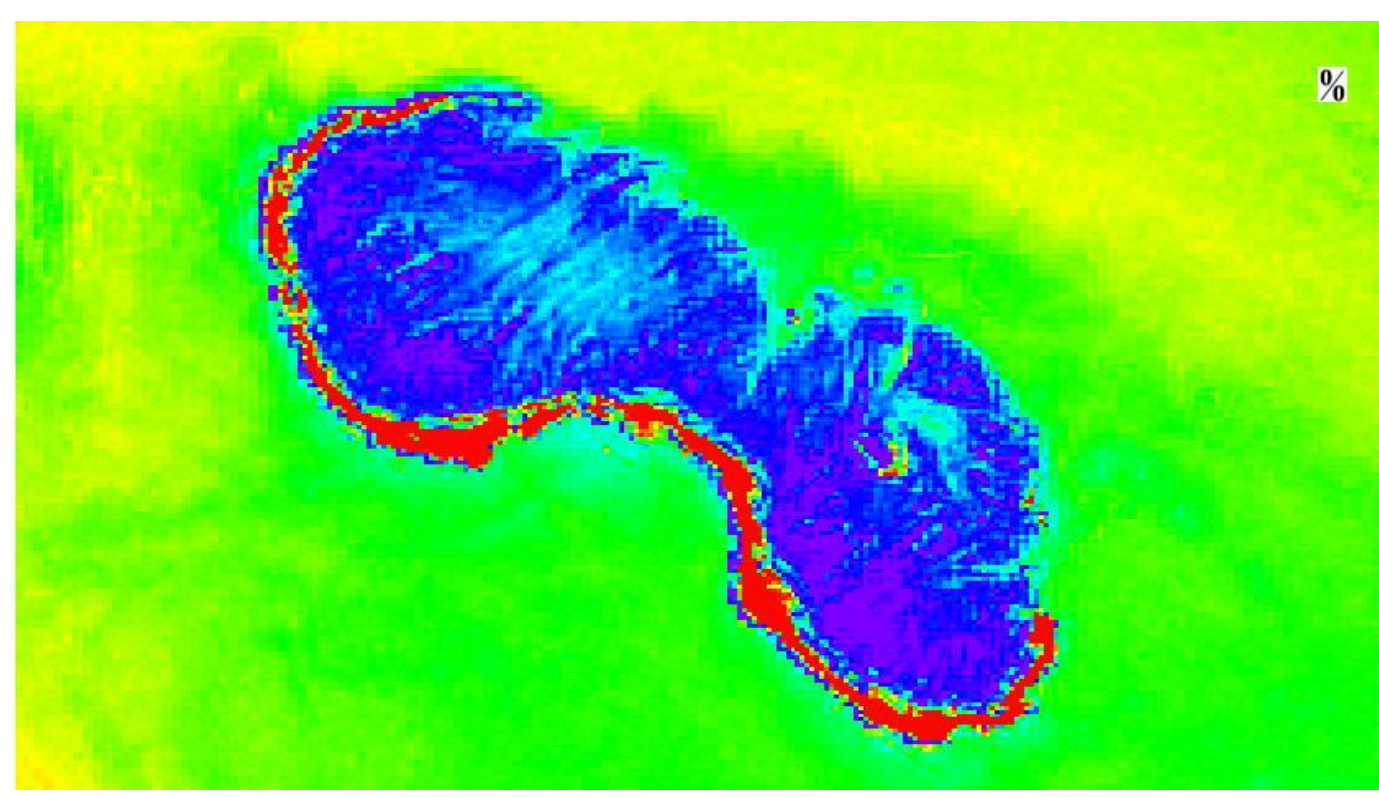

Gambar 5. Defth Invariant Index citra band green dan band blue.

Hasil transformasi metode lyzenga menghasilkan citra DII band Blue dan Green dengan warna komposit rainbow dapat membedakan beberapa kelas objek pada habitat dasar perairan dangkal di PUlau Tikus. 
Terdapat perbedaan warna yang mengindikasikan perbedaan pada kelas habitat perairan dangkal. Citra yang dilakukan transformasi menggunakan metode lyzenga dapat memberikan informasi yang lebih detail dalam mengidentifikasi tiga kelas habitat perairan dangkal yaitu kelas terumbu karang, kelas campuran habitat, pasir, dan makroalga (Purwanto et al 2019). Selanjutnya citra hasil trasnformasi tersebut dilakukan analisis lebih lanjut menggunakan klasifikasi terbimbing.

\section{Klasifikasi Citra}

Hasil klasifikasi citra dikelompokkan menjadi lima kelas yaitu, karang hidup, karang mati, karang bercampur pasir, makro alga, pasir dapat dilihat pada Gambar 6. di bawah ini.
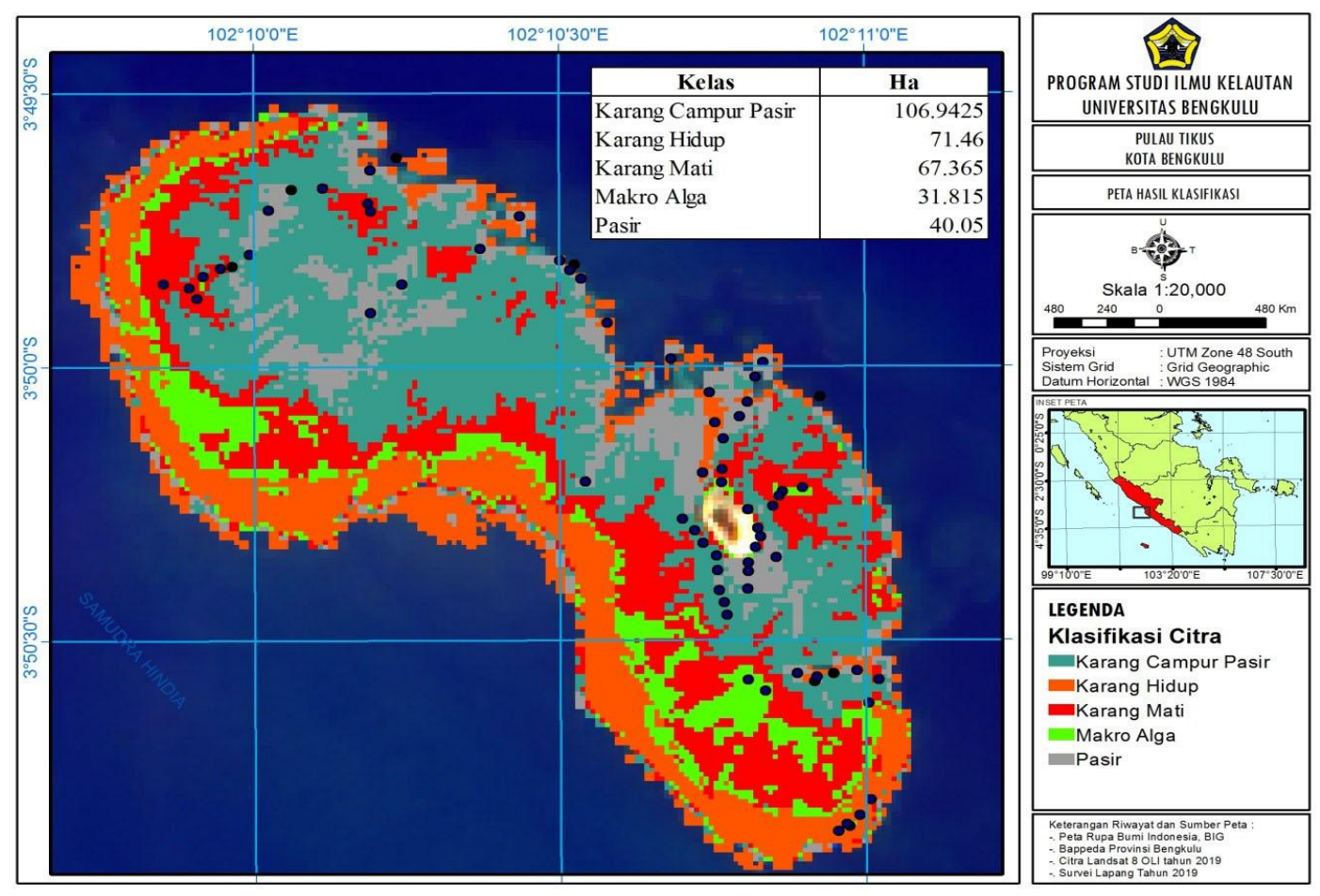

Gambar 6. Klasifikasi citra Landsat 8

Hasil klasifikasi citra Landsat-8 (OLI) berdasarkan skema klasifikasi yang digunakan diperoleh luas area dari lima kelas habitat tersebut masing-masing adalah luasan karang hidup di pulau Tikus seluas 71,46 ha, karang campur pasir 106,9425 ha, karang mati 67,365 ha, makro alga 31,815 ha, dan pasir 40,05 ha. Diketahui bahwa kelas karang bercampur pasir mendominasi habitat dasar perairan pulau Tikus sedangkan habitat pasir mempunyai luasan terendah. Kelas habitat karang hidup mendominasi pada daerah slope/ tubir menghadap samudera hindia, sedangkan kelas lainnya berada pada rataan terumbu karang yang tersebar disekitar Pulau Tikus. Diketahui bahwa Pulau Tikus merupakan pulau kecil dengan rataan terumbu karang yang sangat luas yang dipengaruhi pasang surut, sehingga pada saat surut terendah pada rataan 
terumbu karang terdapat hamparan terumbu karang berada diatas permukaan air sehingga sangat mempengaruhi keberaan habitat terumbu karang hidup disekitarnya. Pada rataan terumbu karang terdapat 3 kelas yang mendominasi yaitu kelas karang bercampur pasir, kelas karang mati, dan kelas pasir.

Beberapa penelitian telah menghasilkan peta terumbu karang guna untuk mengevaluasi berbagai citra resolusi menengah hingga tinggi dan metode klasifikasi berbasis piksel hingga objek. Peta terumbu karang yang menghasilkan akurasi citra yang cukup tinggi sebesar $70.526 \%$ dari citra satelit sentinel 2 dengan metode klasifikasi vervasis piksel di Pulau Sempu (Semedi et al 2019). Pemetaan habitat bentik perairan dangkal dari citra resolusi tinggi Worldview-2 dengan validasi menggunakan in-situ dan drone telah menghasilkan akurasi keseluruhan sebesar 60,6\%-67,5\% (Sugara, et al 2020) Untuk mengetahui pola perubahan terumbu karang dibutuhkan data dengan rentang minimal 10 tahun yaitu diperoleh perubahan terbesar pada kelas rubble/ patahan karang menjadi kelas pasir yang diduga karena faktor oseanografi dan pemanfaatan area terumbu karang untuk pariwisata (Siregar, et al 2020). Beberapa penelitian tersebut dijadikan perbandingan untuk mengevaluasi citra dengan berbabagi resolusi, metode klasifikasi, dan teknik validasi data lapangan secara in-situ dan drone untuk meningkatkan akurasi keseluruhan pada peta yang dihasilkan dengan pendekatan lapangan yang efektif (Wahidin dan Abdulah, 2018).

\section{Uji Akurasi}

Uji akurasi dilakukan untuk menilai kualitas peta yang dihasilkan. Batas akurasi yang dapat diterima untuk peta habitat dasar perairan dangkal berdasarkan pada SNI 7716.2011 tentang Pemetaan Habitat dasar perairan laut dangkal, yaitu $60 \%$. Perhitungan akurasi dengan cara membuat tabel matrik yang membandingkan kelas hasil klasifikasi citra dengan kenyataan dilapangan berdasarkan data sampel uji lapangan (Congalton dan Green, 2009; Lillesand dan Kiefer, 1990).

Tabel 1. Uji akurasi peta habitat terumbu karang pulau Tikus

\begin{tabular}{|c|c|c|c|c|c|c|c|}
\hline $\begin{array}{l}\text { Uji } \\
\text { Lapangan }\end{array}$ & \multirow{2}{*}{$\begin{array}{l}\text { Karang } \\
\text { Campur } \\
\text { Pasir }\end{array}$} & \multirow{2}{*}{$\begin{array}{l}\text { Karang } \\
\text { Hidup }\end{array}$} & \multirow{2}{*}{$\begin{array}{l}\text { Karang } \\
\text { Mati }\end{array}$} & \multirow{2}{*}{$\begin{array}{l}\text { Makro } \\
\text { Alga }\end{array}$} & \multirow{2}{*}{ Pasir } & \multirow[b]{2}{*}{ Total } & \multirow{2}{*}{$\begin{array}{l}\text { UA } \\
(\%)\end{array}$} \\
\hline $\begin{array}{l}\text { Hasil } \\
\text { Klasifikasi }\end{array}$ & & & & & & & \\
\hline $\begin{array}{l}\text { Karang } \\
\text { Campur }\end{array}$ & & & & & & & \\
\hline $\begin{array}{l}\text { Pasir } \\
\text { Karang }\end{array}$ & 8 & & 1 & 3 & & 12 & $67 \%$ \\
\hline Hidup & & 14 & & 1 & & 15 & $93 \%$ \\
\hline Karang Mati & 1 & & 8 & & 1 & 10 & $80 \%$ \\
\hline Makro Alga & 1 & 1 & & 6 & 2 & 10 & $60 \%$ \\
\hline Pasir & & & 1 & 2 & 12 & 15 & $80 \%$ \\
\hline
\end{tabular}




\begin{tabular}{llllllll}
\hline $\begin{array}{l}\text { Uji } \\
\text { Lapangan }\end{array}$ & $\begin{array}{l}\text { Karang } \\
\text { Campur } \\
\text { Pasir }\end{array}$ & $\begin{array}{l}\text { Karang } \\
\text { Hidup }\end{array}$ & $\begin{array}{l}\text { Karang } \\
\text { Mati }\end{array}$ & $\begin{array}{l}\text { Makro } \\
\text { Alga }\end{array}$ & Pasir & Total & $\begin{array}{l}\text { UA } \\
(\%)\end{array}$ \\
\hline $\begin{array}{l}\text { Klasifikasi } \\
\text { Potal }\end{array}$ & 10 & 15 & 10 & 12 & 15 & 62 & \\
$\begin{array}{l}\text { PA (\%) } \\
\text { Akurasi }\end{array}$ & $80 \%$ & $93 \%$ & $80 \%$ & $50 \%$ & $80 \%$ & OA & \\
Total & & & & & & & $77 \%$ \\
\hline
\end{tabular}

Keterangan:

a. $\cup A=$ User Accurary

b. $\mathrm{PA}=$ Producer Accuracy

c. $\mathrm{OA}=$ Overall Accuracy

Uji akurasi terhadap peta hasil klasifikasi dengan menggunakan tabel matrik uji akurasi menghasilkan akurasi keseluruhan (overall accuracy - OA), producer accuracy dan user accuracy masing-masing kelas, seperti ditampilkan pada Tabel 1. Nilai OA sebesar $77 \%$ menunjukkan bahwa secara keseluruhan klasifikasi yang dilakukan baik. Terdapat 3 kelas habitat yang bercampur pada kelas lain yaitu kelas karang campur pasir yang masuk pada kelas makroalga dan kelas karang hidup atau sebaliknya yang menyebabkan pada 3 kelas ini diperoleh akurasi UA dan PA menjadi rendah dari 50\%-67\%. Akurasi yang rendah tersebut mengindikasikan bahwa terdapat kemiripan nilai spektral pada kelas tersebut sehingga menyebabkan terjadi kesalahan klasifikasi. Dalam penelitian lainnya untuk meningkatkan akurasi pemetaan pada habitat dasar perairan dangkal dapat menerapkan beberapa koreksi pada prapemrosesan citra yaitu koreksi sunglint yang dapat meningkatkan akurasi sebesar 7\% (Anggoro, et al 2016). Selain itu juga dapat menggunakan metode klasifikasi berbasis objek yang terbukti dapat meningkatkan akurasi sebesar 14\% (Anggoro, et al 2018). Peningkatan akurasi (OA) pemetaan habitat dasar perairan dangkal dapat dilakukan uji coba menggunakan sensor resolusi tinggi (Ikonos, QuickBird, Geoye-1, Worldview-2) dengan enam kelas yang dapat meningkatkan akurasi keseluruhan berkisar antara 70-90\% (Yamano, 2013).

\section{KESIMPULAN}

Pemetaan dan sebaran terumbu karang dapat dilakukan dengan memanfaatkan data penginderaan jauh, yaitu Citra Lansdat-8 (OLI). Klasifikasi citra Landsat-8 (OLI) berdasarkan skema klasifikasi yang digunakan diperoleh bahwa luas area dari lima kelas habitat di Pulau Tikus tersebut masing-masing adalah luasan karang hidup seluas 71,46 ha, karang campur pasir 106,9425 ha, karang mati 67,365 ha, makro alga 31,815 ha, dan pasir 40,05 ha. Diketahui bahwa kelas karang bercampur pasir mendominasi habitat dasar perairan pulau Tikus sedangkan habitat pasir mempunyai luasan terendah. Berdasarkan uji akurasi yang didapatkan sebagai nilai kualitas peta dengan nilai OA sebesar $77 \%$ menunjukkan bahwa secara keseluruhan klasifikasi yang dilakukan baik. 


\section{UCAPAN TERIMA KASIH}

Penulis mengucapkan Fakultas Pertanian Universitas Bengkulu atas dana hibah penelitian pembinaan yang diberikan untuk penelitian ini dan juga kepada Dinas Kelautan dan Perikanan Kota Bengkulu, serta tim penelitian Pulau Tikus yang membantu penulis selama survei lapangan.

\section{DAFTAR PUSTAKA}

Purwanto, A, Setiawan, K, Ginting, D. 2019. Pemanfaatan Data Penginderaan Jauh untuk Ekstraksi Habitat Perairan Laut Dangkal di Pantai Pemuteran, Bali, Indonesia. Jurnal Kelautan Tropis. Vol22. 165. 10.14710 .

Anggoro, A., Siregar, V P., Agus, S B.. 2016. The Effect of Sunglint on Benthic Habitats Mapping in Pari Island Using Worldview-2 Imagery.Procedia Environmental Sciences.Vol-33. Pages 487-495.

Anggoro, A., Sumartono, E., Siregar, V P., Agus, S B., Purnama, D., Supriyono, Puspitosari, D A., Listyorini, T., Sulistyo and Parwito. 2018. Comparing Object-based and Pixel-based Classifications for Benthic Habitats Mapping in Pari Islands. IOP Conf. Series: Journal of Physics: Conf. Series 1114. 012049.

Bakhtiar, D. dan Z. Ta'alidin. 2015. Laporan Kajian Identifikasi Terhadap Kondisi Pulau Tikus. Dinas Kelautan dan Perikanan Provinsi Bengkulu, Bengkulu.

Congalton, R.G, K.Green. 2009. Assesing the Accuracy of Remotely Sensed Data. Principles and Practices. $2^{\text {th }}$ Edition. New York: CRC Press Taylor and Francis Group.

English, S. C.Wilkinson, dan V. Baker. 1994. Survey Manual for Tropical Marine Resources. Australian Institute of Marine Science.Townsville. 368 pp.

Giyanto. 2013. Metode Transek Foto Bawah air untuk penilaian kondisi terumbu karang. Oseana. XXXVIII: 47-61.

Green, E.P., P.J. Mumby, A.J. Edwards, C.D. Clark. 2002. Remote sensing handbook for tropical coastal management. Paris: UNESCO.

Jaya, I N S. 2002. Separabilitas Spektral Beberapa Jenis Pohon Menggunakan Citra Compact Airborne Spectograph Imager (CASI): Studi Kasus di Kebun Raya Bogor. Jurnal Manajemen Hutan. Vol. VII, No. 2: hal 57-73. 
Lillesand, T.M., dan R.W. Kiefer. 1990. Remote Sensing and Image Interpretation. (Alih Bahasa Dulbahri et al.). Gadjah Mada University Press. Yogyakarta.

Lyzenga, D.R. 1981. Remote sensing of bottom reflactance and water attenuation parameters in shallow water using aircraft and Landsat data. International J Rem Sens. 2:71-82.

Mumby, P.J., E.P. Green, C.D. Clark, A. Edward. 1997. Reef habitat assesment using airborne remote sensing. Procciding: $8^{\text {th }}$ International Coral Reef Symposium.

Purwadhi, F.S.H. 2001. Interpretasi Citra Digital, PT Grasindo, Jakarta.

Semedi, Bambang \& B, Alif \& Luthfi, Oktiyas. (2019). Pemanfaatan Data Citra Satelit Sentinel-2 Untuk Asesmen Habitat Dasar Perairan Pantai Selatan Sempu Kabupaten Malang. JFMR-Journal of Fisheries and Marine Research. 3. 155-161. 10.21776/ub.jfmr.2019.003.02.1.

Siregar, V, Agus, S, Subarno, T, Sunuddin, A, Aziizah, N.2020. Analisis Perubahan Habitat Dasar Perairan Dangkal Menggunakan Citra Satelit Resolusi Tinggi Di Karang Lebar, Kepulauan Seribu. Jurnal Ilmu dan Teknologi Kelautan Tropis. 12. 37-51. 10.29244/jitkt.v12i1.25528.

Sugara, A, Siregar, V, Agus, S. 2020. Klasifikasi Habitat Bentik Perairan Dangkal Dari Citra Worldview-2 Menggunakan Data In-Situ Dan Drone. Jurnal Ilmu dan Teknologi Kelautan Tropis. 12. 135-150. 10.29244/jitkt.v12i1.26448.

Sutanto. 1986. Penginderaan Jauh DasarJilid I. Gadjah Mada University, Yogyakarta.

Wahidin, N, Abdullah, R. 2018. Pemetaan Substrat Dasar Perairan Dangkal Menggunakan Drone Komersial Dan Teknik Fotogrametri.Prosiding Seminar Nasional. Vol-1.hal-612.

Yamano, H. 2013. Multispectral application: In Goodman, J.A., S.J. Purkis, and S.R. Phinn (eds.) 2013. Coral reef remote sensing: a guide for mapping, monitoring and management. Springer. 51-78pp.

Zhu, G.B. 2003. Remote sensing image analysis based on hierarchical multi-resolution structures. Geomat and Inform Sci of Wuhan Univ. 28(3): 315-320. 